\title{
Absence of Clostridium difficile stool carriage in asymptomatic volunteers
}

\author{
M Hell $^{1 *}$, K Sickau' ${ }^{1}, G$ Chmelizek1, JM Kern², M Maass², S Huhulescu ${ }^{3}$, F Allerberger ${ }^{3}$ \\ From International Conference on Prevention \& Infection Control (ICPIC 2011) \\ Geneva, Switzerland. 29 June - 2 July 2011
}

\section{Introduction / objectives}

Clostridium difficile $\hat{\mathrm{A}}$ is considered a leading cause of hospital-acquired diarrhea. Currently there arê̂A published case-reports of symptomatic Health-Care-Workers $(\mathrm{HCW}) \hat{\mathrm{A}}$ and one report demonstrating $\hat{A}$ transmission of C. diff from patient to HCW. Therefore, we initiated a prospective study to evaluate the prevalence of asymptomatic $C$. difficile stool carriage among healthcare workers at a single university hospital comparing them $\hat{A}$ to nonhealthcare workers to asses the risk for HCW's acquiring Clostridium difficile.

\section{Methods}

The study population consisted of 113 healthy HCW's of clinical departments with a high incidence of Â CDI in inpatients. The 128 controls were taken from the administration department of a Food Company and from frozen stool samples of healthy subjects from a colon cancer screening program. Both groups were comparable in ageand sex-distribution. From April to July 2010, in total 241 stool specimens were tested for toxigenic culture of $C$ diff. $51 \%$ of stool samples $(58 / 113)$ of the study population and all control-samples $(\mathrm{n}=128)$ were confirmed by broth enrichment technique at the National Reference Laboratory for $C$. difficile in Vienna.

\section{Results}

Both investigated study-groups $(\mathrm{n}$-total $=241)$ were negative for Clostridium difficile by both culture techniques (direct plating and broth enrichment method).

\section{Conclusion}

We conclude, therefore, that healthy HCWs are probably not at risk for aquiring $\mathrm{C}$ diff spores from contacts

${ }^{1}$ Dep.of Hospital Epidemiology and Infection Control, University Hospital Salzburg, Salzburg, Austria

Full list of author information is available at the end of the article with CDI-patients. They are themselves no risk for spreading C. diff spores in health-care facilities. Data about C.diff carriage in the community (up to $3 \%$ ) demonstrates a possible overestimation.

\section{Disclosure of interest}

None declared.

\section{Author details}

'Dep.of Hospital Epidemiology and Infection Control, University Hospital Salzburg, Salzburg, Austria. ${ }^{2}$ Institut of Hygiene, microbiology and infectious diseases, University Hospital Salzburg, Salzburg, Austria. ${ }^{3}$ National Reference Laboratory for Clostridium difficile, Austrian Agency for Health and Food Safety (AGES), Vienna, Austria.

Published: 29 June 2011

doi:10.1186/1753-6561-5-S6-P183

Cite this article as: Hell et al: Absence of Clostridium difficile stool carriage in asymptomatic volunteers. BMC Proceedings 2011 5(Suppl 6): P183.
Submit your next manuscript to BioMed Central and take full advantage of:

- Convenient online submission

- Thorough peer review

- No space constraints or color figure charges

- Immediate publication on acceptance

- Inclusion in PubMed, CAS, Scopus and Google Scholar

- Research which is freely available for redistribution

Submit your manuscript at www.biomedcentral.com/submit

\section{() Biomed Central}

C Biomed Central

C 2011 Hell et al; licensee BioMed Central Ltd. This is an open access article distributed under the terms of the Creative Commons Attribution License (http://creativecommons.org/licenses/by/2.0), which permits unrestricted use, distribution, and reproduction in any medium, provided the original work is properly cited. 